\title{
ICTs and School Education
}

\author{
Nuria Aris and Lara Orcos
}

\section{Universidad Internacional de La Rioja and Universidad Nacional de Educación a Distancia}

\begin{abstract}
Nowadays, there exist lots of ICTs that teachers use as teaching tools. In this work, we introduce the theoretical context of the study of using ICTs in school education, then we present the method that will be used in order to achieve our goals. This work constitutes the groundwork to continue the study of ICT and its use in teaching.
\end{abstract}

Keywords - ICTs, School Education, teaching paradigms.

\section{INTRODUCTION}

$\mathrm{W}$ E live in a society each day more digitalized and ICTs take part of both private and professional lives of most people. In the educational environment and student life cycle, interaction with ICTs begins in early childhood and lasts until the professional fulfillment. Technology has advanced and continues to progress, and with this dynamism its educational use is also modified. Therefore one of the main challenges of education is to make students know how to use technology as a tool for their own production, communication and learning throughout life.

In early childhood education we can find children very motivated by the use of ICTs-related games. This implies that, from very early stages, they are well acquainted with the use of phones, tablet and others. In a playful way, the child makes a progressive approach and that learning is in itself an initiation to ICTs.

At the stage of primary education, the child consolidates the instrumental learning and acquires basic skills. At this stage the constructivist pedagogical approach emphasizes the creation and production of knowledge by the student in relation to the environment. ICTs are used as teaching tools and resources to facilitate the development of the knowledge and skills of students. Therefore, it assumes great importance the role of teacher. Most teachers appreciate the benefits of ICTs because they represent a way to motivate students, to vary the classes, to individualize learning, etc. It is also true that the use of these technologies can cause them insecurity and rejection, since students typically handled ICTs better than themselves.

In this way, one of the fundamental goals of compulsory education is to prepare students to work in a digitized society.

In this article we reflect about it, about the impact of ICTs in education and the "how and how much" to use technology in the teaching and learning process. Equilibrium needs to be found as the use of ICTs should support the methods used to practice the competences required for a subject and the learning process of the individual.

\section{METHOD}

We propose a descriptive study, based on a deep review of specific literature, in order to show the relationship between the process of teaching and learning in ICTs, its theoretical foundation, application and regarding motivation, as well as the raise of the evaluation.

We intend to confirm the relationship between ICTs, its teaching process and the potential they represent in motivating students in the first, especially primary education stages. Our concerns are prompting us to give answers to questions such as:

- Is there a relationship between teaching and learning process with ICTs and motivation?

- What role do the teacher and the method used have?

- Can we establish relationship between playful motivation in ICTs and performance in a specific area?

Considering all these reflections, we initiated this first theoretical review as a starting point for contextualized in ICTs future research, based on leisure motivation and its application in instrumental learning and specifically in relation to mathematics.

\section{THEORETICAL REVIEW}

\section{A. ICTs related contents}

Before delving into the different dimensions presented above, it is interesting to establish a conceptual demarcation of the meanings associated with ICT terminology.

In this article 'the information and communication technologies' are used as a global term for all types of technique, including the computer, tablet, mobile phone, digital camera, interactive displays and the network. This term refers both to hardware, which can provide the components that are included on a computer system, and software, related to programs that can be used in the computer system and network resources. The term has an extensive content and includes both the treating information and the communicating concepts (Livingstone, 2012, Gulek et al., 2005).

In this study the sentence "A use of ICTs in education 'means that students use a laptop and resources it offers as well as those offered by the network. The focusing is that the students use it, not the teacher.

The phrase 'frequent use of ICTs' is used to describe the work of a group of students who used the computer and its resources in all educational activities in practice to develop all digital skills. All material used is in digital format, for example the training manual.

Comparing with the previous sentence, the phrase 'limited use of ICTs' is used in this study to describe the work of a group of students using computer and ICTs resources just to develop the digital competence. Computer and the resources it offers are considering as a complement to teaching and as a way to vary the usual teaching. The material used by students is usually printed. In the study, the frequent or limited computer use is approached from the perspective of the student, not from the teacher use.

In order to define 'digital skills' is used the definition of the European Communities (2012), which establishes that people should know how to use ICTs in a safe and critical way, both in their profession and in the spare time, and how to use them is used to communicate. The basic digital skills are "search, store, evaluate, produce, present and exchange information, and to communicate and participate in collaborative networks with the help of ICTs (European Commission 2012).

In the article the definition of the Royal Spanish Academy is used to describe the concept of 'education' as the 'action and effect of teaching "(RAE 2013). In the study, this is interpreted as the action of the teacher and what the student can do with the teacher's action. 
Another concept used, the concept of 'learning' is also defined with the help of RAE: "Action and effect of learning an art, trade or otherwise" (RAE 2013). This concept refers to the action of the student and the outcome of this process. It indicates that there is a permanent change in knowledge.

\section{B. ICTs in School. ICTs evolution in the first stages of compulsory education}

Technology has advanced and continues to progress, and it has also progress the way in which it is used. Today, the use is complex due to the fact that computers are connected to different networks and technology in general is more integrated into our lives. However, it is the connection between the use of ICTs and pedagogy is remarkable and this relation is in fashion at the moment.

Researching about it, four paradigms that represent different uses of ICT in education are found: The use of ICTs as an automatic device, as a tool, as a forum and as a means (Scheerens et al 2007).

These different paradigms of computer use exist in parallel, but were developed chronologically.

- The First paradigm, an automatic apparatus, is influenced by the ideas of behaviorism and structuralism (Valiente 2010). This paradigm is represented by educational programs in which students have to fill the hole left in a sentence with a word or a number. The student is active and receives direct feedback to his response. It is a mechanical work done by the student.

- The Second paradigm, the tool one, is influenced by the pedagogy of Jean Piaget. This pedagogy is based on the child's curiosity, the desire to know more and his own activity. The teacher's role changes from being someone who teaches another person to a person who guides students in their learning process. ICTs have supported this change of focus in the classroom. There are a high number of ways to use ICTs as a tool, such as finding written and recorded information or writing and making presentations. We can say that the purpose of teaching within this paradigm is that students use the computer for creative activities being much more active (Fleiser, 2011, Livingstone, 2012).

- The Third paradigm describes technology as an integrated part in our daily lives, as a forum for communication and interaction to share experiences and to play part in virtual worlds. There are many examples of this paradigm (Penuel, 2006).

- The last paradigm was added by Salinas (2005): the use of ICTs as a medium. In the school context, it means that school and administrative information is distributed through the network. Educational platforms are used and it also increase the number of distance courses that are conducted many times throughout the network. In this paradigm, the user is even more active. The development of the Internet has been a decisive factor for users since anyone has the chance to be published in the network. For school, it means that students can be published for example in a blog, and thus can reach a larger audience.

In the classroom today, it is common the mixture of methods based on different pedagogical tendencies due to the fact that the materials require different methods to afford different parts of subject and because students take advantage of a variety of teaching methods (Cabero et al 2005a and 2005b). The methods are not opposed in the teaching process, they complement.

What students do nowadays in classes is the same as it was done before, without digital tools (Vidal Puga 2011). Technology is used to find information, to write, and to support students to make presentations. There is no perceived a substantial difference between the use of ICTs in Spanish classes compared to other European countries (European Commission 2012), which means that the Spanish teachers, as European teachers, have remained cautious in regards to adopt entirely digitized class.

\section{Constructivism}

Teachers who use ICTs say that they do it because it is a way to motivate students, to vary power classes and to individualized learning. The authenticity of the material also attracts teachers to use technology. Often, the successful use of ICTs depends on the teacher. At the same time, there are teachers who express doubts about using ICTs as a lack of preparation in teaching applicability.

Thomas et al. (2013) suggest that contemporary ICTs play an important role in supporting the methods based on constructivism, adding an authentic teaching input, building relevant exercises for students and working cooperatively. It is important to remark that ICTs, themselves, are not a teaching method, however often facilitate or reinforce certain methods. So we can establish a direct connection between the development of ICTs and pedagogical ideas of constructivism (Vidal Puga 2006 Silvernail et al, 2011, Touron 2010, Slavin et al. 1996).

Indeed, there are those who say that the impact of ICTs on pupil's performance does not appear without a constructivist teaching, that is, it's important to leave traditional methods away so as the use can be beneficial, which explains one of the goals the introduction of ICTs, to change the way we work in class more focused ways to the student. The "constructivism" is a pedagogical idea that emphasizes the creation and production of knowledge by the student in relation to the environment. In school debates, constructivism is often contrasted with 'tradition give lectures' by the teacher, in which knowledge is considered to be something transferable from one person to another. In this tradition, the teacher has a very pronounced role in class while in constructivism the student is focused in class. In the classroom today, it is common that both methods are mixed. In this situation, we consider the computer a tool and a resource in teaching that reinforces the teaching methods chosen.

This is evident in important aspects of constructivism such as motivation and autonomous learning. The student demonstrates the significant reflection process and the creation of increasingly complex and elaborate knowledge. This favors the creation of holistic knowledge (Pozo and Monereo, 2009, Touron 2010), contingent upon the competence learning. In this way the student, rather than acquiring knowledge, takes main role in its construction. It takes an active, autonomous and self-regulating role, since he takes the learning control. Throughout the ICTs, there are activated a high number of basic cognitive processes, including the selection and retention of information, the organization and development of new information, the integration of the information into prior knowledge and applying to the new knowledge situations (Huber, 2008). All this reverses in the student an increasing motivation for the task to developing (Peter, 2012).

The autonomous dynamic that sets the student himself is one of the most important and motivational aspects because he is the one who decides and takes leadership. Nevertheless, all this process depends on how the activity has been approached by the teacher. The teacher should be a helper and a guide on intellectual access to learning with and from ICTs. He should also focus the subject considering the perspective of the students: how they could better approach it, with what kind of difficulties they may come up with, what kind of media or additional support could be helpful, etc. (Zabalza, 2002).

There are studies that suggest that autonomy encourages them and they can achieve better results (Bolivar, 2007). These elements can be the key in boosting the motivation for the learning and teaching process orientated the use of ICTs (Comer, 1999; Slavin, 1996) . 
Taking into account the complementarities of the aspects described above, the proposed model is established, which articulates the teaching and learning process and with motivation and self-employment, all it aimed at achieving competences in the first educational levels.

In relation to these aspects it makes more sense to apply the concept of shared evaluation, which is defined as that evaluation process which is carried out jointly by the teacher and the student and also by the students considering the dialogue between the teacher with their students on the evaluation of learning and the processes taking place.

Thus, the act of evaluating is a joint construction between both parties. That is, it is an assessment from the interaction between the students themselves, with the teacher, and also from individual reflection itself.

We describe and explain these forms of assessment which should include the following levels simultaneously:

- Evaluation of independent work: Making own decisions is encouraged from the autonomous initiative. The student becomes aware of what its own learning process has brought him, arguing the "whys" and the perception of the degree of effort. It is interesting to mention that the self evaluation is not an automatic skill, is not a process that usually takes place, so it needs to be taught and supported (De Miguel, 2004 and 2006). It is important the role of the teacher in this learning guide (Alvarez et al. 2007). Knowing how to self evaluate is inextricably linked to the skills of critical thinking and the achievement of basic skills.

- The joint evaluation: The joint evaluation is a constitutive element of formative assessment that has a dual function, since it allows us to keep a record of the actions taken by students. It is based on the following levels of analysis:

- The first level, which can be described as "outside" made by both the teacher and the rest of the students from the contrast between the different contributions of each student.

- A second level, "inside" level that allows the student's selfassessment. For all this, we understand that this practice promotes the building of metacognitive capacity of the student, who is responsible for the regulation of his own learning (Pan, Pan, or Chang Lee, 2010).

\section{CONCLUSSIONS}

- We want to insist on the proper initial character of this study because we are at the first implementation of this experience. This review allows us to understand the benefits of the adoption of ICTs and its relation to the motivational effects in the early stages of education.

- It might be assumed that investment in ICTs implementation projects in recent years have increased and changed the daily classroom use. But the truth is that it seems that there is no much difference in the work done by students and very often there is only a qualitative change. Students seek and find information in different ways; they find more information that before and present it in ways that were previously impossible.

- In this way, considering this initial research, we believe it is crucial to continue the research on the teacher educational intervention for future implementations of ICTs.

- Its potential is sensed not only in motivation but in the degree of the learning level in the students. They value their own effort and their learning undertaken with ICTs. The mixture of freedom and advice as well as all the "scaffolding" which sets the use of ICTs and the sharing creates a certain cooperative learning that leads to obtain positive results.
- The peer assessment also shows us a suitable way to demonstrate the competence achievement. In this direction, Bain (2005) explains that the best results are achieved by those teachers who believe students can change.

- In this way we can gradually gain a greater understanding of the learning process of students and also a set of guidelines that can lead the intervention on the teaching and learning processes oriented to the basic skills achievement (Boekaerts, 2001). The results motivate us to keep researching and applying it.

\section{REFERENCES}

[1] Álvarez, B.; González, C. y García, N. (2007). La motivación y los métodos de Evaluación como variables fundamentales para estimular el aprendizaje autónomo. Red U. Revista de Docencia Universitaria, $n^{\circ} 2$. http://www.redu.um.es/Red_U/2

[2] Bolivar, A. (2007). Diseñar y evaluar por competencias en la Universidad. El EEES como reto. Colección Formación e Innovación Educativa en la Universidad. Vigo: Vicerreitoría de Formación e Innovación Educativa. Universidade de Vigo.

[3] Cabero, Julio; Gisbert, Mercè (2005). Formación en Internet. Guía para el diseño de materiales didácticos. Sevilla: MAD.

[4] Cabero, J., Llorente, $\mathrm{M}^{\mathrm{a}}$ Carmen (2005). «Las plataformas virtuales en el ámbito de la teleformación» [artículo en línea]. Alternativas.

[5] Cannon, J., y Scharmann, L. (1996). Influence of a cooperative early field experience on preservice elementary teachers' science selfefficacy. Science Education, 80(4); 419-436. doi:10.1002/(SICI)1098237X(199607)80:4<419::AID-SCE3>3.3.CO;2-W

[6] Comer, J.P. et al. (ed.) (1999). Child by Child. The Comer process for change in Education.Nueva York: Teachers College Press

[7] De Miguel Diaz, M. (2004). Evaluación de los aprendizajes de los alumnos. Programa de formación inicial para la docencia universitaria. ICE. Curso 2004-05. Universidad de Oviedo.

[8] De Miguel Diaz, M.. (2006) (coord.). Metodologías de enseñanza y aprendizaje para el desarrollo de competencias. Orientaciones para el profesorado universitario ante el Espacio Europeo de Educación Superior. Madrid: Alianza Editorial.

[9] European commission (2012) first european survey on language competences. Executive summary en European commission [en línea]. Disponible en Http://www.surveylang.org/media/ executivesummaryoftheeslc_210612.pdf [2014-08-26]

[10] Fleischer, Håkan (2011) What is our current understanding of one-to-one computer projects: A systematic narrative research review. Educational Research Review, ISSN 1747-938X, 11/2011, Volume 7, Issue 2, p. 107122.

[11] Gulek, James Cengiz \& Demirtas, Hakan (2005) Learning With Technology: The Impact of Laptop Use on Student Achievement. The Journal of Tecnology, Learning, and Assessment. Volume 3, Number 2, January 2005.

[12] Huber, G. L. (2008) Aprendizaje activo y metodologías educativas. Revista de Educación, no extraordinario 2008: 59-81.

[13] Livingstone, Sonia (2012) Critical reflections on the benefits of ICT in education, Oxford Review of Education, 38:1, 9-24, ISSN 0305-4985.

[14] Pan, P. J. D., Pan, G. H. M., Lee, C. Y., y Chang, S. S. H. (2010). University students' perceptions of a holistic care course through cooperative learning: Implications for instructors and researchers. Asia Pacific Education Review, 11(2): 199-209. Doi:10.1007/s12564-010-9078-0

[15] Pedró, Francesc (2012). Connected minds: technology and today's learners. Paris: Centre for Educational Research and Innovation, OECD.

[16] Penuel, William R. (2006). Implementation and Effects of One-to-One Computing Initiatives: A Research Synthesis. Journal of Research on Technology in Education. Spring 2006: Volume 38 Number 3.

[17] Pozo, J.I. y Monereo, C. (2009). Introducción: la nueva cultura del aprendizaje universitario o por qué cambiar nuestras formas de enseñar y aprender. En J.I. Pozo y M.P. Pérez Echeverría (coord.), Psicología del aprendizaje universitario: la formación en competencias. Madrid: Morata: 9-28.

[18] Scheeens j. \&et al.(2007) review and meta analyses of school and teaching effectiveness. The netherlands: university of twente. 
[19] Salinas, Jesús (2005). «La gestión de los entornos virtuales de formación». En: Seminario Internacional: La Calidad de la Formación en Red en el Espacio Europeo de Educación Superior

[20] Silvernail, David, L. \& Pinkham, Caroline, A. \& Wintle, Sarah, E. \& Walker, Leanne C. \& Bartlett, Curtney, L. (2011). A Middle School Oneto-One Laptop Program: The Maine Experience. Main Education Policy Research Institute, University of Southern Maine.

[21] Slavin, R.E. et al. (1996). Every Child, Every School: Success for All. Thousand Oaks, California: Corwin Press

[22] TouronJ. (2010). Talent Search as an assessment process. Keynote presentation, European Council for High Ability, Paris, Julio, 7-9.

[23] Thomas, m. \& reinders, h. \& warschauer, m. (2013). Computer-assisted language learning: the Role of digital media and incremental change. Contemporary computer-assisted language learning [recurso electrónico]. Thomas, michael \& reinders, hayo \& warschauer, mark (red.) 1-12. London: bloomsbury academic.

[24] Valiente, o. (2010). 1-1 in education: current practice, international comparative research Evidence and policy implications, oecd education working papers, no. 44, oecd publishing [en línea].

[25] Vidal Puga, María del Pilar (2006). Investigación de las TIC en la educación, Revista Latinoamericana de Tecnología Educativa, 5 (2), 539-552. Disponible en: http://campusvirtual.unex.es/revistas/index.php/ relatec/article/view/293/277 [2014-03-27]

[26] Zabalza, M.A. (2002). La enseñanza universitaria. El escenario y sus protagonistas. Madrid: Narcea.

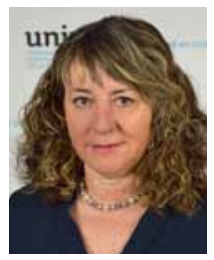

Nuria Aris Redó recevide the M.S. in Psicopedagogy from Universitat Oberta de Cataluña and the Ph. D. degree in Human and Social Sciences from the Universidad Internacional de Cataluña. Currentlu, she is professor and academic coordinator at Universidad Internacional de La Rioja, Logroño, Spain. Her research interests include studies in emotional management, teaching skills and the Nurnout Syndrome in Educators.

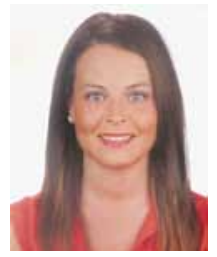

Lara Orcos Palma recevide the M.S. in Chemistry from Universidad de La Rioja, the M.S. in BioChemistry from Universidad de Salamanca, the B.S. of Secondary Teaching from Universidad de La Rioja and the B.S. in Chemical Science and Technology from Universidad Nacional de Educación a Distancia, now she is beginning the doctorate at the Universidad Nacional de Educación a Distancia in teaching skills and working as director of work order degree of Facultad de Educación at the Universidad Internacional de La Rioja (UNIR) 